https://doi.org/10.52418/moldovan-med-j.64-3.21.11

UDC: $616.98: 578.834 .1$

Open 2 Access

\title{
Risk factors of SARS-CoV-2 infection
}

\author{
Eugene Calenici \\ Department of Interventional Cardiology, Institute of Cardiology, Chisinau, the Republic of Moldova \\ Author's ORCID iD, academic degrees and contribution are available at the end of the article \\ ${ }^{*}$ Corresponding author - Eugene Calenici, e-mail: eugene.calenici@gmail.com \\ Manuscript received December 21, 2020; revised manuscript July 05, 2021; published online September 10, 2021
}

\begin{abstract}
Background: Review is based on the biggest observational population study of all the risk factors of COVID-19 infection. The study was carried out in Royal College of General Practitioners, Oxford, and covering over 4 million of people. Were studied and analyzed risk factors as: age, sex and ethnicity, socioeconomic level, living space dimensions, rural-urban population, body mass index, smoker status, pregnancy, hypertension, chronic kidney disease, ischemic heart disease, chronic respiratory diseases including asthma, and chronic obstructive pulmonary disease, and type 1 and 2 diabetes. Patient variable with malignancy and immunocompromised status was separated due to the small number of patients in each group.

Conclusions: By September 2020 more than 28.000 articles had been published related to COVID-19 in less than 9 months, 211 new papers every day. Most of them had small population of the studies. In the investigated sample, it was found that increasing age, male sex, economic deprivation, urban location and black ethnicity were associated with higher chances of testing positive for SARS-CoV-2. Active smoking decreased the chance of a positive test. The review covers the most important subjects influencing the development of severe infection outcomes.

Key words: SARS-CoV-2, COVID-19, risk factors.
\end{abstract}

Cite this article

Calenici E. Risk factors of SARS-CoV-2 infection. Mold Med J. 2021;64(3):54-61. https://doi.org/10.52418/moldovan-med-j.64-3.21.11.

\section{Introduction}

In late 2019 - early 2020, the world was hit by a pandemic caused by the virus causing Severe Acute Respiratory Syndrome (SARS-CoV-2), an infection also called COVID-19. This is a new coronavirus that was primarily reported to the World Health Organization (WHO) as a group of cases of viral pneumonia of unknown aetiology in Wuhan, China, on 31 December 2019. It is currently known that the cause of the disease is coronavirus (COVID-19), which affects both the upper and lower respiratory tract. On 30 January 2020, the WHO declared the outbreak of COVID-19 a global public health emergency. Since then, the infection has continued to spread around the world and was described by the WHO as a pandemic on 11 March 2020.

COVID-19 virus belongs to the family of single-stranded RNA viruses, some of which have been previously described to be responsible for the Severe Acute Respiratory Syndrome (SARS) and Middle East Respiratory Syndrome (MERS). Although the symptoms and clinical presentation of COVID-19 are similar to SARS and MERS, the rate of spread is greater.

In the United Kingdom, the first cases were detected at the end of January 2020; the transmission among the population began at the end of that month. Initial reports from China, Italy and Spain clinically described the char- acteristics of people diagnosed with COVID-19 and the risk factors, which include old age, male sex, pre-existing cardiovascular diseases, high blood pressure and diabetes. However, the most recent researches to date have been done among in-patients with COVID-19, i.e., the risk factors for infection in the general population have not been directly evaluated.

The aim of the study was to evaluate the potential risk factors that could influence the spread, and change the management and prevention of the spread of this new type of virus.

The Research and Supervision Centre of the Royal College of General Practitioners in Oxford includes over 500 health centres in both urban and rural areas, covering over 4 million people.

\section{Material}

A cross-sectional study of patients in the Network of the Research and Surveillance Centre in Oxford, who were tested for SARS-CoV-2 between 28 January and 4 April 2020, was performed. Pseudonymized results were taken from electronic primary health care records. These data enabled estimating the living space sizes, the isolation level and rural-urban classification. Starting with the last week of January 2020, research and surveillance centres submitted nasopharyngeal smears for SARS-CoV-2 testing in patients with symptoms of influenza or respiratory infection. 
The analytical specifics of RT-PCR assays for SARSCoV-2 are greater than $95 \%$ and the analytical sensitivity of the assays is usually $90-95 \%$, with high performance.

Patients registered with the research and surveillance centres as of 30 September 2019, and who had a record in their medical sheet reporting a positive or negative result for SARS-CoV-2 were only people with a positive test or negatively coded, and not those under suspicion.

\section{Studied variables}

The following independent demographic aspects were studied as factors: age, sex and ethnicity, using an ontology to maximize case identification; socioeconomic level using the English quintile index for multiple deprivation; living space dimensions based on the patient's pseudonymized address; and rural-urban division. The most recent record of the following clinical variables was included, which are similar to those associated with higher susceptibility to influenza: body mass index (BMI), smoker status, pregnancy, hypertension, chronic kidney disease, ischemic heart disease, chronic respiratory diseases, including asthma and chronic obstructive pulmonary disease, and type 1 and 2 diabetes. Patient variable with malignancy and immunocompromised status was created due to the small number of patients in each group. Malignancy was identified using the most recently recorded disease codes and prescriptions of prednisolone and antirheumatic drugs as a surrogate for immunosuppression with a positive test for SARS-CoV-2.

\section{Statistical methods}

Descriptive statistics and reported counts were used for categorical data and distribution measures for continuous data. Collinearity was checked by measuring the variation of the inflation factor for each covariate - all were considered within acceptable limits, with a maximum value below 2.0. New sensitivity analyses were performed using only complete cases, non-ethnic data imputed from the census data.

\section{Results}

Between 28 January and 4 April 2020, 587 patients with positive results on SARS-CoV-2 and 3215 with negative results were obsessed with the surveillance programme. The first positive case reported on 30 January 2020 reaching the number of 100 cases on 17 March 2020. In total, 2190 (57.6\%) of 3802 patients were women and 2497 (65.7\%) were white (tab. 1).

The data are $\mathrm{n}(\%)$. SARS-CoV-2 = severe acute respiratory syndrome - coronavirus $2 . \mathrm{BMI}=$ body mass index. ${ }^{*}$ The level of socio-economic deprivation was assessed at a practical level using the English Index of Multiple Deprivation Quintiles. † BMI categories were based on the WHO classification (normal weight $18.5-24.9 \mathrm{~kg} / \mathrm{m}^{2}$, overweight 25.0 $29.9 \mathrm{~kg} / \mathrm{m}^{2}$, obese $30.0-39.9 \mathrm{~kg} / \mathrm{m}^{2}$, severely obese $\geq 40 \mathrm{~kg} /$ $\mathrm{m}^{2}$ )

In the univariate analysis, the chances of testing positive for SARS-CoV-2 were higher among the elderly, non-white men, and people living in more disadvantaged areas (tab. 2 ). The chances of a positive test were lower in households from two to four or five to eight people. The clinical factors in the univariate analysis, chronic kidney diseases, obesity, malignancy or immunocompromise, diabetes, chronic respiratory diseases, chronic heart diseases, and hypertension were associated with higher odd ratios of a positive SARSCoV-2 test.

In case of active smoker, he has had a decreased level for a positive COVID test. In the multivariable analysis, adjusted for all other variables in tab. 3, male sex remained independently associated with SARS-CoV-2 positive testing. The age linked variable: children and people aged 40-64 years were at a lower risk $(5.36,3.28-8.76)$ compared to adult ones and people aged 75 years and older $(5.23,3.00-$ 9.09) were at the highest risk. Black people were at a higher risk of testing positive for SARS-CoV-2 (4.75, 2.65-8.51), compared to white people. Were associated with higher odd ratios of SARS-CoV-2 test - urbanized areas (4.59, 3.57-5.90). In the adjusted analysis, people with chronic kidney disease were more likely to be tested positive for SARS-CoV-2 than those without it (1.91, 1.31-2.78), but without a significant association with other chronic conditions. Smoking cigarettes was associated with lower chances of a positive SARS-CoV-2 test result (adjusted OR 0-49, (95\% CI) 0.34-0.71). Higher odd ratios of a positive test among obese people was found compared to those with normal weight (1.41, 1.04-1.91).

The review of the literature suggested that COVID-19 affected men aged between 30 and 65, and about half of the patients were over 50 years old. There is a higher risk of a similar positive SARS-CoV-2 test in men as in people aged over 40. It is known that the chance of a positive SARSCoV-2 test increases with higher population density due to the increased social mix, which correlates with the finding of a high level of a positive test in urban areas.

Socially disadvantaged areas were found to be associated with a higher risk of other respiratory infections, and thus the risk of death from COVID-19 is higher in the poorest parts of the UK.

The decrease in the socio-economic level was associated with the increase of a positive test, independently of the area of the place of residence, urban location and smoking. No association was found between household size and the risk of SARS-CoV-2 positivity, despite previous data of a higher risk of transmission through household contacts. Social distancing measures could have influenced the transmission speed and areas. Some data raised concerns about the potential increased risk of complications associated with COVID-19 among black and Asian people, but there were few epidemiological studies that have assessed the risk by ethnicity. An analysis of 3370 people in the UK admitted to the ICU (Intensive Care Unit) with confirmed positive COVID-19 found that 402 (11.9\%) were black, 486 (14.4\%) were Asian and 2236 (66.4\%) were white [35], compared to the national figures that were of $3.3 \%, 7.5 \%$ and $86.0 \%$. These results were not adjusted for socio-demographic potential or clinical confusions [36]. 
Table 1. Demographic and clinical characteristics of the study cohort [50]

\begin{tabular}{|c|c|c|c|}
\hline SARS-CoV-2 test result & Participants 3802 & Pregnancy & \\
\hline Negative & $3215(84.6 \%)$ & No & $3742(98.4 \%)$ \\
\hline Positive & $587(15.4 \%)$ & Yes & $60(1.6 \%)$ \\
\hline Missing data & 0 & Missing data & 0 \\
\hline \multicolumn{4}{|l|}{ Age } \\
\hline $0-17$ & $499(13.1 \%)$ & BMIt & \\
\hline $18-39$ & $666(17.5 \%)$ & Normal weight & $1296(34.1 \%)$ \\
\hline $40-64$ & $1316(34.6 \%)$ & Overweight & $1095(28.8 \%)$ \\
\hline $65-74$ & $557(14.7 \%)$ & Obesity & $680(17.9 \%)$ \\
\hline$\geq 75$ & $764(20.1 \%)$ & Morbid obesity & $145(3.8 \%)$ \\
\hline Missing data & 0 & Missing data & $586(15.4 \%)$ \\
\hline \multicolumn{4}{|l|}{ Sex } \\
\hline Women & $2190(57.6 \%)$ & Hypertension & \\
\hline Men & $1612(42.4 \%)$ & No & $2708(71.2 \%)$ \\
\hline Missing data & 0 & Yes & $1094(28.8 \%)$ \\
\hline Ethnicity & & Missing data & 0 \\
\hline white people & $2497(65.7 \%)$ & & \\
\hline Asian people & $152(4.0 \%)$ & Chronic kidney diseases & \\
\hline black people & $58(1.5 \%)$ & No & $3595(94.6 \%)$ \\
\hline others & $81(2.1 \%)$ & Yes & $207(5.4 \%)$ \\
\hline Missing data & $1014(26.7 \%)$ & Missing data & 0 \\
\hline \multicolumn{4}{|l|}{ Level of socio-economic deprivation* } \\
\hline 5 (less deprived) & $1855(48.8 \%)$ & Diabetes & \\
\hline 4 & $633(16.6 \%)$ & No & $3299(86.8)$ \\
\hline 3 & $646(17.0 \%)$ & Yes & $503(13.2)$ \\
\hline 1 and 2 (more deprived) & $668(17.6 \%)$ & Missing data & 0 \\
\hline Missing data & 0 & & \\
\hline $\begin{array}{l}\text { Number of people living in a common } \\
\text { space }\end{array}$ & & Chronic heart diseases & \\
\hline 1 & $824(21.7 \%)$ & No & $3202(84.2 \%)$ \\
\hline $2-4$ & $2341(61.6 \%)$ & Yes & $600(15.8 \%)$ \\
\hline $5-8$ & $408(10.7 \%)$ & Missing data & 0 \\
\hline$\geq 9$ & $135(3.6 \%)$ & & \\
\hline Missing data & $94(2.5 \%)$ & Chronic respiratory diseases & \\
\hline Population density & & No & $3544(93.2 \%)$ \\
\hline Rural & $1986(52.2 \%)$ & Yes & $258(6.8 \%)$ \\
\hline Urban & $1816(47.8 \%)$ & Missing data & 0 \\
\hline Missing data & 0 & & \\
\hline Smoker status & & Cancers or immune comprom & \\
\hline Non-smoker & $1125(29.6 \%)$ & No & $3164(83.2 \%)$ \\
\hline Active smoker & $413(10.9 \%)$ & Yes & $638(16.8 \%)$ \\
\hline Ex-smoker & $1753(46.1 \%)$ & Missing data & 0 \\
\hline Missing data & $511(13.4 \%)$ & & \\
\hline
\end{tabular}


Table 2. Univariable analysis of demographic and clinical risk factors for testing positive for SARS-CoV-2 [50]

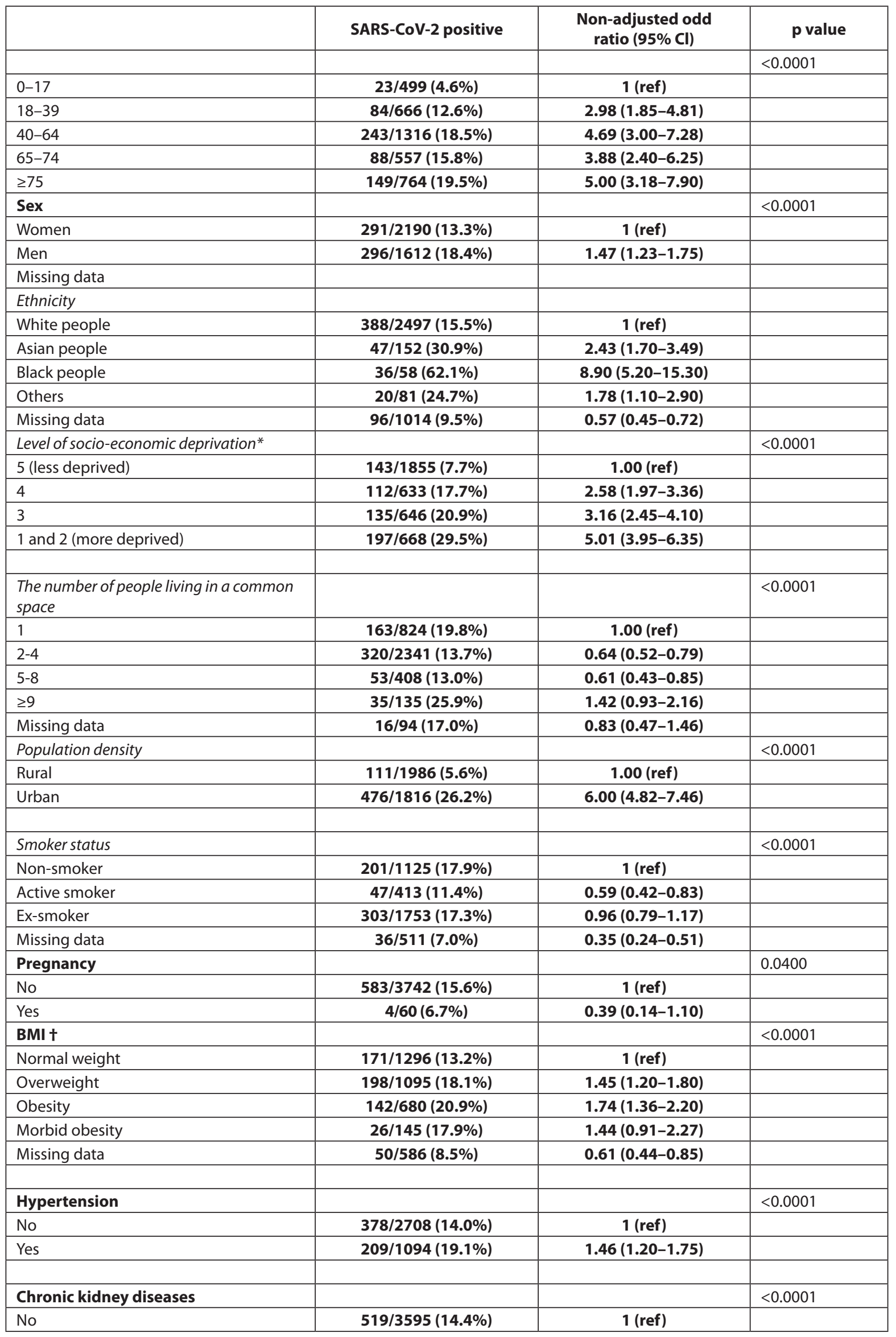




\begin{tabular}{|c|c|c|c|}
\hline Yes & $68 / 207(32.9 \%)$ & $2.90(2.14-3.93$ & \\
\hline Diabetes & & & $<0.0001$ \\
\hline No & $473 / 3299(14.3 \%)$ & 1 (ref) & \\
\hline Yes & $114 / 503(22.7 \%)$ & $1.75(1.40-2.20)$ & \\
\hline Chronic heart diseases & & & $<0.0001$ \\
\hline No & $451 / 3202(14.1 \%)$ & 1 (ref) & \\
\hline Yes & $136 / 600(22.7 \%)$ & $1.79(1.44-2.20)$ & \\
\hline Chronic respiratory diseases & & & $<0.0001$ \\
\hline No & $529 / 3544(14.9 \%)$ & 1 (ref) & \\
\hline Yes & $58 / 258(22.5 \%)$ & $1.65(1.21-2.25)$ & \\
\hline $\begin{array}{l}\text { Oncological or immunocompromising } \\
\text { diseases }\end{array}$ & & & $<0.0001$ \\
\hline No & $460 / 3164(14.5 \%)$ & 1 (ref) & \\
\hline Yes & $127 / 638(19.9 \%)$ & $1.46(1.17-1.82)$ & \\
\hline
\end{tabular}

Table 3. Multivariable analysis of risk factors for SARS-CoV-2 positive testing [50]

\begin{tabular}{|l|c|l|}
\hline \multicolumn{1}{|c|}{ Age } & $\begin{array}{c}\text { Non-adjusted odd } \\
\text { ratios (95\% Cl) }\end{array}$ & $<\mathbf{0 . 0 0 0 1}$ \\
\hline $0-17$ & 1 (ref) & \\
\hline $18-39$ & $2.83(1.69-4.74)$ & \\
\hline $40-64$ & $5.36(3.28-8.76)$ & \\
\hline $65-74$ & $4.41(2.52-7.69)$ & \\
\hline$\geq 75$ & $5.23(3.00-9.09)$ & \\
\hline Sex & & $<0.0001$ \\
\hline Women & 1 (ref) & \\
\hline Men & $1.55(1.27-1.89)$ & \\
\hline Missing data & & \\
\hline Ethnicity & & \\
\hline White people & 1 (ref) & \\
\hline Asian people & $1.46(0.94-2.29)$ & \\
\hline Black people & $4.75(2.65-8.51)$ & \\
\hline Others & $1.71(0.97-3.01)$ & \\
\hline Missing data & & \\
\hline $\begin{array}{l}\text { Level of socio-economic } \\
\text { deprivation* }\end{array}$ & & \\
\hline 5 (less deprived) & & \\
\hline 4 & $1.51(1.13-2.03)$ & \\
\hline 3 & $2.35(1.78-3.11)$ & \\
\hline 1 - 2 (more deprived) & $2.03(1.51-2.71)$ & \\
\hline & & \\
\hline $\begin{array}{l}\text { The number of people living in a } \\
\text { common space }\end{array}$ & & \\
\hline 1 & $0.97(0.77-1.23)$ & \\
\hline $2-4$ & $0.86(0.57-1.31)$ & \\
\hline $5-8$ & $1.29(0.80-2.07)$ & \\
\hline$\geq 9$ & & \\
\hline Missing data & & \\
\hline Population density & & \\
\hline Rural & & \\
\hline & & \\
\hline
\end{tabular}

\begin{tabular}{|l|c|c|}
\hline Urban & $4.59(3.57-5.90)$ & \\
\hline Smoker status & & \\
\hline Non-smoker & 1 (ref) & \\
\hline Active smoker & $0.49(0.34-0.71)$ & \\
\hline Ex-smoker & $0.87(0.69-1.10)$ & \\
\hline BMl † & & 0.0090 \\
\hline Normal weight & 1 (ref) & \\
\hline Overweight & $1.26(0.99-1.61)$ & \\
\hline Obesity & $1.41(1.04-1.91)$ & \\
\hline Morbid obesity & $1.28(0.78-2.10)$ & \\
\hline Missing data & & \\
\hline Hypertension & & 0.3100 \\
\hline No & 1 (ref) & \\
\hline Yes & $0.89(0.69-1.14)$ & \\
\hline Chronic kidney diseases & & \\
\hline No & $1($ ref $)$ & \\
\hline Yes & $1.91(1.31-2.78)$ & \\
\hline Diabetes & & 0.8300 \\
\hline No & 1 (ref) & \\
\hline Yes & $1.03(0.78-1.36)$ & \\
\hline Chronic heart diseases & & 0.1800 \\
\hline No & $1.21(0.92-1.60)$ & \\
\hline Yes & & \\
\hline Chronic respiratory diseases & & \\
\hline No & & \\
\hline Yes & & \\
\hline $\begin{array}{l}\text { Oncological or } \\
\text { immunocompromising } \\
\text { diseases }\end{array}$ & & \\
\hline No & & \\
\hline Yes & & \\
\hline & & \\
\hline & & \\
\hline & & \\
\hline
\end{tabular}




\section{Discussion}

The study has shown that black people were more likely to test positive for SARS-CoV-2 than white ones, which remained significant even after adjusting for comorbidities, such as high blood pressure and diabetes, whose prevalence is higher in black people. Other socio-economic factors that we did not examine, such as high-risk professions, level of education, income and barriers to health care, could have contributed to this association and should be explored as soon as possible [29, 30, 32, 33].

Regular reviews showed that people with COVID-19 who have chronic comorbidities, such as hypertension, diabetes and cardiovascular diseases are at high risk for severe COVID-19 evolution [38]. Risk factors for SARS-CoV-2 infection may be different, and no evidence was found of an association between these conditions and a positive SARS$\mathrm{CoV}-2$ test. It was detected that chronic kidney disease and obesity were associated with testing positive for SARS$\mathrm{CoV}-2$. Both factors - chronic kidney disease and obesity were associated with a higher risk of other respiratory infections, angiotensin-converting enzyme inhibitors, which are recommended as treatments for chronic kidney disease and were postulated to impact SARS-CoV-2 interactions on the host cell. However, there is no observational evidence to support this effect, and further analyses to investigate the relationship between drugs, chronic diseases, and SARSCoV-2 positivity would be evaluated.

Previous studies reported that smoking is associated with a higher risk of hospitalization in intensive care unit or death among people with COVID-19 [46]. Yet, several studies have reported a low prevalence of smokers among people with COVID-19 [47, 48]. A Chinese study found that only $137(12.6 \%)$ of 1085 patients with COVID-19 were current smokers, compared to the proportion of $27.7 \%$ of adult smokers in the general population, another analysis of cases in the Centres for Disease Control and Disease Prevention in the US detected that only 96 (1.3\%) of 7162 COVID-19 cases were active smokers, compared to $13.7 \%$ of smokers in the general US population. However, it should be admitted that in these studies it is sometimes difficult to identify active smokers among patients with COVID-19.

The data obtained show that active smoking was associated with a decrease in the chances of having a positive COVID-19 test result. There are several plausible reasons for this result. Active smoking could affect the viral load of the nasopharynx and therefore affect the sensitivity of the RT-PCR test, rather than protection against actual infection, although this effect is not known in the RT-PCR test for influenza. Smokers are more likely to have a cough, which means they may also be more likely to be tested positive for SARS-CoV-2 than non-smokers, even if they are SARSCoV-2 negative. This more frequent test could increase the proportion of smokers with a negative SARS-CoV-2 result in our sample, which would harm our results. However, the share of smokers in our study was low. In addition, former smokers and people with chronic lung disease would also be expected to cough more, but these groups were not more likely to be tested positive for SARS-CoV-2. Therefore, the relationship between smoking and SARS-CoV-2 infection should be further investigated. Nicotine in turn may decrease the sensitivity of angiotensin-converting enzyme receptors, the place used by SARS-CoV-2 for entering cells, although studies found an increase in the concentration of angiotensin-converting enzyme 2 in lungs among smokers and people with chronic obstructive pulmonary disease. The findings should not be used to conclude that smoking prevents SARS-CoV-2 infection or to encourage continued smoking, especially given the well-documented damage to overall health caused by smoking, there may be alternative explanations for these findings.

Although the study group of primary care patients is likely to be more similar to the general population than that of hospital-based studies, there is a risk of bias in selection, as the results may reflect groups of patients who were more likely to come for evaluation and be selected for SARS-CoV-2 testing in accordance with the guidelines. If certain groups (e.g., men, people in disadvantaged areas, non-smokers, and black people) may only come or be tested when they are in a more serious condition, those who were tested may be more likely to be positive for COVID-19. In contrast, groups with lower thresholds for presentation could be tested with less severe symptoms and therefore are more likely to be tested negative. Population surveys should provide consistent test levels by subgroups as far as possible to reduce the risk of selection bias. Although RT-PCR testing is the gold standard for SARS-CoV-2 Diagnosis, the overall sensitivity of the test in the clinic, may be reduced by factors, such as smear technique and time relative to the onset of symptoms. Therefore, some SARS-CoV-2 cases could have been missed, especially among patients with lower viral loads.

Additional data are needed to establish the epidemiology of SARS-CoV-2, especially with regard to emerging factors, such as ethnicity, deprivation, population density and smoking.

\section{Conclusions}

Primary health care network data provide important information on the epidemiology of SARS-CoV-2, although the study was limited by small sample and selection of patients who came for SARS-CoV-2 testing through routine health care services. It is necessary to continuously study the factors that influence the development of the epidemic, the severity of symptoms, and the conditions in which COVID infection spreads faster.

\section{References}

1. Lai CC, Shih TP, Ko WC, Tang HJ, Hsueh PR. Severe acute respiratory syndrome coronavirus 2 (SARS-CoV-2) and coronavirus disease-2019 (COVID-19): the epidemic and the challenges. Int J Antimicrob Agents. 2020;55(3):105924. doi: 10.1016/j.ijantimicag.2020.105924.

2. Kinross P, Suetens C, Gomes Dias J, et al. Rapidly increasing cumulative incidence of coronavirus disease (COVID-19) in the European Union/ European Economic Area and the United Kingdom,1 January to 15 
March 2020. Euro Surveill. 2020;25(11):2000285. doi: 10.2807/1560-7917. ES.2020.25.11.2000285

3. Wu Z, McGoogan JM. Characteristics of and important lessons from the coronavirus disease 2019 (COVID-19) outbreak in China: summary of a report of 72314 cases from the Chinese Center for Disease Control and Prevention. JAMA. 2020;323:1239-42. doi: 10.1001/jama.2020.2648.

4. Zhou F, Yu T, Du R, et al. Clinical course and risk factors for mortality of adult inpatients with COVID-19 in Wuhan, China: a retrospective cohort study. Lancet. 2020;395(10229):1054-62. doi: 10.1016/S0140-6736(20)30566-3.

5. Lipsitch M, Swerdlow DL, Finelli L. Defining the epidemiology of Covid-19 - studies needed. N Engl J Med. 2020;382(13):1194-96. doi: 10.1056/ NEJMp2002125.

6. Fleming DM, Miles J. The representativeness of sentinel practice networks. J Public Health (Oxf). 2010;32(1):90-96. doi: 10.1093/pubmed/fdp087.

7. Correa A, Hinton W, McGovern A, et al. Royal College of General Practitioners Research and Surveillance Centre (RCGP RSC) sentinel network: a cohort profile. BMJ Open. 2016;6(4):e011092. doi: 10.1136/ bmjopen-2016-011092.

8. de Lusignan S, Correa A, Smith GE, et al. RCGP Research and Surveillance Centre: 50 years' surveillance of influenza, infections, and respiratory conditions. Br J Gen Pract. 2017;67(663):440-41. doi: 10.3399/bjgp17X692645.

9. Fleming DM. Weekly returns service of the Royal College of General Practitioners. Commun Dis Public Health. 1999;2(2):96-100.

10. Pebody RG, Whitaker H, Ellis J, et al. End of season influenza vaccine effectiveness in primary care in adults and children in the United Kingdom in 2018/19. Vaccine. 2020;38(3):489-97. doi: 10.1016/j.vaccine.2019.10.071.

11. Pebody RG, Warburton F, Andrews N, et al. Uptake and effectiveness of influenza vaccine in those aged 65 years and older in the United Kingdom, influenza seasons 2010/11 to 2016/17. Euro Surveill. 2018;23(39):1800092. doi: 10.2807/1560-7917.ES.2018.23.39.1800092.

12. Fleming DM, Durnall H. Ten lessons for the next influenza pandemic - an English perspective: a personal reflection based on community surveillance data. Hum Vaccin Immunother. 2012;8(1):138-45. doi: 10.4161/hv.8.1.18808.

13. de Lusignan S, Borrow R, Tripathy M, et al. Serological surveillance of influenza in an English sentinel network: pilot study protocol. BMJ Open. 2019;9(3):e024285. doi: 10.1136/bmjopen-2018-024285.

14. de Lusignan S, Lopez Bernal J, Zambon M, et al. Emergence of a novel coronavirus (COVID-19): protocol for extending surveillance used by the Royal College of General Practitioners Research and Surveillance Centre and Public Health England. JMIR Public Health Surveill. 2020;6(2):e18606. doi: $10.2196 / 18606$.

15. de Lusignan S, Sherlock J, Ferreira F, O’Brien S, Joy M. Household presentation of acute gastroenteritis in a primary care sentinel network: retrospective database studies. BMC Public Health. 2020;20(1):445. doi: 10.1186/s12889020-08525-8.

16. de Lusignan S, McGee C, Webb R, et al. Conurbation, urban, and rural living as determinants of allergies and infectious diseases: Royal College of General Practitioners Research and Surveillance Centre Annual Report 2016-2017. JMIR Public Health Surveill. 2018;4(4):e11354. doi: 10.2196/11354.

17. Corman VM, Landt O, Kaiser M, et al. Detection of 2019 novel coronavirus (2019-nCoV) by real-time RT-PCR. Euro Surveill. 2020;25(3):2000045. doi: 10.2807/1560-7917.ES.2020.25.3.2000045.

18. NHS England and NHS Improvement. Guidance and standard operating procedure: COVID-19 virus testing in NHS laboratories [Internet]. London: NHS England; c2020- [updated 2020 March 16; cited 2020 Apr 30]. Available from: https://www.england.nhs.uk/coronavirus/wpcontent/ uploads/sites/52/2020/03/guidance-and-sop-covid-19-virustesting-innhs-laboratories-v1.pdf.

19. BioPortal. COVID-19 Surveillance Ontology [Internet]. Stanford: National Center for Biomedical Ontology; 2005- [cited 2020 Apr 30]. Available from: https://bioportal.bioontology.org/ontologies/COVID19

20. Department of Health and Social Care. Coronavirus (COVID-19): notice under reg 3(4) of the Health Service Control of Patient Information Regulations 2002 - general [Internet]. London: DHSC; 2020- [updated 2020 March 20; cited 2020 May 5]. Available from: https://www.gov.uk/government/ publications/coronavirus-covid-19-notification-of-data-controllersto-share-information/coronavirus-covid-19-notice-under-regulation34-of-the-health-service-control-of-patient-information-regulations2002-general.
21. Health Research Authority. Defining research table [Internet]. London: NHS England; c2018- [updated 2017 Oct; cited 2018 Feb 6]. Available from: http://www.hra-decisiontools.org.uk/research/docs/DefiningResearchTable_Oct2017-1.pdf.

22. Tippu Z, Correa A, Liyanage $\mathrm{H}$, et al. Ethnicity recording in primary care computerised medical record systems: an ontological approach. J Innov Health Inform. 2017;23(4):920. doi: 10.14236/jhi.v23i4.920.

23. Department for Communities and Local Government. The English Index of Multiple Deprivation (IMD) 2015 - Guidance [Internet]. London: DCLG; 2020- [cited 2020 Apr 30]. Available from: https://assets.publishing.service.gov.uk/government/uploads/system/uploads/ attachment_data/file/464430/English_Index_of_Multiple_Deprivation_2015_-_Guidance.pdf

24. World Health Organization. Physical status: the use and interpretation of anthropometry: Report of a WHO Expert Committee. Geneva: WHO;1995.

25. Buuren A, Groothuis-Oudshoorn K. Multivariate imputation bychained equations in R. J Stat Softw. 2011;45(3):1-67.

26. Mertens BJA, Banzato E, deWreede LC. Construction and assessment of prediction rules for binary outcome in the presence of missing predictor data using multiple imputation and crossvalidation: methodological approach and data-based evaluation. Biom J. 2020;62(3):724-41. doi: 10.1002/bimj.201800289.

27. Office for National Statistics. KS201EW: ethnic group [Internet]. London: The Office; 2011- [cited 2020 Apr 30]. Available from: https://www. nomisweb.co.uk/census/2011/ks201ew

28. Office for National Statistics. Census geography: An overview of the various geographies used in the production of statistics collected via the UK census [Internet]. London: The Office; 2011- [cited $2020 \mathrm{Apr}$ 30]. Available from: https://www.ons.gov.uk/methodology/geography/ ukgeographies/censusgeography

29. Yi Y, Lagniton PNP, Ye S, Li E, Xu RH. COVID-19: what has been learned and to be learned about the novel coronavirus disease. Int J Biol Sci. 2020;16(10):1753-66. doi: 10.7150/ijbs.45134.

30. Wang KW, Gao J, Wang H, et al. Epidemiology of 2019 novel coronavirus in Jiangsu Province, China after wartime control measures: a populationlevel retrospective study. Travel Med Infect Dis. 2020;35:101654. doi: 10.1016/j.tmaid.2020.101654.

31. Smith S, Morbey R, de Lusignan S, Pebody RG, Smith GE, Elliot AJ Investigating regional variation of respiratory infections in a general practice syndromeic surveillance system. J Public Health (Oxf) 2020;fdaa014. doi: 10.1093/pubmed/fdaa014.

32. Office for National Statistics. Coronavirus (COVID 19) roundup [Internet]. London: The Office; 2011- [cited 2020 May 5]. Available from: www.ons.gov.uk/peoplepopulationandcommunity/healthandsocialcare/ conditionsanddiseases/articles/coronaviruscovid19roundup/2020-03-26

33. Bi Q, Wu Y, Mei S, et al. Epidemiology and transmission of COVID19 in 391 cases and 1286 of their close contacts in Shenzhen, China: a retrospective cohort study. Lancet Infect Dis. 2020;20(8):911-919. doi: 10.1016/S1473-3099(20)30287-5.

34. Pareek M, Bangash MN, Pareek N, et al. Ethnicity and COVID-19: an urgent public health research priority. Lancet. 2020;395(10234):14211422. doi: 10.1016/S0140-6736(20)30922-3.

35. Intensive Care National Audit \& Research Centre. ICNARC report on COVID-19 in critical care [Internet]. London: ICNARC; 2020- [cited 2020 Apr 30]. Available from: https://www.icnarc.org/DataServices/ Attachments/Download/c31dd38d-d77b-ea11-9124-00505601089b

36. UK Government. Population of England and Wales [Internet]. London: The Government; 2020- [cited 2020 Apr 30]. Available from: https:// www.ethnicity-facts-figures.service.gov.uk/uk-population-by-ethnicity/ national-and-regional-populations/population-of-england-andnwales/ latest

37. Carson AP, Howard G, Burke GL, Shea S, Levitan EB, Muntner P. Ethic differences in hypertension incidence among middle-aged and older adults: the multi-ethnic study of atherosclerosis. Hypertension. 2011;57(6):1101-07. doi: 10.1161/HYPERTENSIONAHA.110.168005.

38. Yang J, Zheng Y, Gou X, et al. Prevalence of comorbidities and its effects in patients infected with SARS-CoV-2: a systematic review and metaanalysis. Int J Infect Dis. 2020;94:91-95. doi: 10.1016/j.ijid.2020.03.017. 
39. McDonald HI, Thomas SL, Millett ER, Nitsch D. CKD and the risk of acute, community-acquired infections among older people with diabetes mellitus: a retrospective cohort study using electronic health records. Am J Kidney Dis. 2015;66(1):60-68. doi: 10.1053/j.ajkd.2014.11.027.

40. Su G, Trevisan M, Ishigami J, Matsushita K, Stålsby Lundborg C, Carrero JJ. Short- and long-term outcomes after incident pneumonia in adults with chronic kidney disease: a time-dependent analysis from the Stockholm Creatinine Measurement project. Nephrol Dial Transplant. 2020;35(11):1894-1900. doi: 10.1093/ndt/gfz119.

41. Zammit C, Liddicoat H, Moonsie I, Makker H. Obesity and respiratory diseases. Int J Gen Med. 2010;3:335-43. doi: 10.2147/IJGM.S11926.

42. Vaduganathan M, Vardeny O, Michel T, McMurrary JVJ, Pfeffer MA, Solomon SD. Renin-angiotensin-aldosterone system inhibitors in patients with Covid-19. N Engl J Med. 2020;382(17):1653-59. doi: 10.1056/ NEJMsr2005760.

43. Mancia G, Rea F, Ludergnani M, Apolone G, Corrao G. Renin-angiotensin-aldosterone system blockers and the risk of Covid-19. N Engl J Med. 2020;382(25):2431-2440. doi: 10.1056/NEJMoa2006923.

44. Reynolds HR, Adhikari S, Pulgarin C, et al. Renin-angiotensin-aldosterone system inhibitors and risk of Covid-19. N Engl J Med. 2020;382(25):2441-2448. doi: 10.1056/NEJMoa2008975.
45. Mehta N, Kalra A, Nowacki AS, et al. Association of use of angiotensinconverting enzyme inhibitors and angiotensin II receptor blockers with testing positive for coronavirus disease 2019 (COVID-19). JAMA Cardiol. 2020;5(9):1020-1026. doi: 10.1001 /jamacardio.2020.1855.

46. Vardavas CI, Nikitara K. COVID-19 and smoking: a systematic review of the evidence. Tob Induc Dis. 2020;18:20. doi: 10.18332/tid/119324.

47. Parascandola M, Xiao L. Tobacco and the lung cancer epidemic in China. Transl Lung Cancer Res. 2019;8(Suppl 1):S21-30. doi: 10.21037/ tlcr.2019.03.12.

48. Chow N, Fleming-Dutra K, Gierke R, et al. Preliminary estimates of the prevalence of selected underlying health conditions among patients with coronavirus disease 2019 - United States, February 12 - March 28, 2020. MMWR Morb Mortal Wkly Rep. 2020;69(13):382-86. doi: 10.15585/ mmwr.mm6913e2.

49. Godoy P, Castilla J, Soldevila N, et al. Smoking may increase the risk of influenza hospitalization and reduce influenza vaccine effectiveness in the elderly. Eur J Public Health. 2018;28(1):150-55. doi: 10.1093/eurpub/ ckx130.

50. de Lusignan S, Dorward J, Correa A, et al. Risk factors for SARS-CoV-2 among patients in the Oxford Royal College of General Practitioners Research and Surveillance Centre primary care network: a crosssectional study. Lancet Infect Dis. 2020;20(9):1034-1042. doi: 10.1016/ S1473-3099(20)30371-6.

\section{Author's ORCID iD and academic degrees \\ Eugene Calenici, MD, PhD Applicant - https://orcid.org/0000-0003-3804-2241}

\section{Author's contribution}

EC conceptualized the idea, conducted literature review, wrote the manuscript and revised the final text.

\section{Funding}

This study was supported by Institute of Cardiology and journal publication fee was covered by Philip Morris Sales and Marketing SRL. The review was the author's initiative. The author is independent and takes responsibility for the integrity of the data and accuracy of the data analysis.

Ethics approval and consent to participate

No approval was required for this study.

\section{Conflict of Interests}

There are no known conflicts of interests and financial or non-financial support associated with this publication. 